\title{
The Role of Eggs as an Important Source of Nutrition in Human Health
}

\author{
Mahendra Pal ${ }^{1, *}$, Judit Molnár ${ }^{2}$ \\ ${ }^{1}$ Narayan Consultancy on Veterinary Public Health and Microbiology, Anand-388001, Gujarat, India. \\ 21 1/9 Palánkutca, 9200 Mosonmagyaróvár, Hungary.
}

How to cite this paper: Mahendra Pal, Judit Molnár. (2021) The Role of Eggs as an Important Source of Nutrition in Human Health. International Journal of the Science of Food and Agriculture, 5(1), 180-182.

DOI: $10.26855 /$ ijfsa.2021.03.023

Received: February 4, 2021

Accepted: March 2, 2021

Published: March 23, 2021

*Corresponding author: Mahendra Pal, Narayan Consultancy on Veterinary Public Health and Microbiology, Anand-388001, Gujarat, India. Email: palmahendra2@gmail.com

\begin{abstract}
Nutrition plays a very important role in healthful living. Daily consumption of balanced diet is pertinent to mainatin good health. Eggs contain both macronutrients as well as micronutrients, which are essential to the body. Eggs are one of the richest sources of complex protein ( $5 \mathrm{~g} /$ piece). The complex protein need for the normal healthy diet is $75-80$ g. Therefore, eggs help to provide the amount of aminoacids required for the human body. Amino acids perform many functions. It is primarily a building block of proteins, thus helping the human body to develop. Proteins increase the muscle mass and prevent their breakdown. This also serves as an energy reserve that is why a high protein egg is called a complex protein. In addition, to its positive biological values, it has significant cholesterol content as well. Due to this reason, it is imperative to reduce consumption of eggs in case of high-cholesterol. Eggs are also suitable for enriching the foods in order to increase the nutritional value of the product. The consumption of raw egg must be avoided as it can be the source of infections in humans. Contamination of eggs poses a high risk to food safety. Good hygienic practice is highly imperative to mainatin high quality and safety of eggs. In the manuscript, we summarize the most important properties of the eggs in healthy diet. Furthermore, we are also looking for a place in international gastronomy. It is hoped that the nutritionists and other scientists can get a new knowledge through our publication.
\end{abstract}

\section{Keywords}

Biological values, Complex protein, Eggs, Food safety, Functional foods, International gastronomy

\section{Introduction}

Due to rising economy, the consumption of eggs is increasing across the globe. Eggs are consumed globally by both sexes; all age groups, in all seasons, and in rural and urban settings. Eggs play an important role in the international gastronomy $[1,2]$ and healthy diet as well. The high nutritional value of this brilliant protein source is recognized worldwide in nutrition and medicine. Health and nutrition science institutions in several countries (USA, Australia, New Zealand, Canada, UK, WHO, Spanish Heart Foundation) recommend eating eggs regularly as part of a healthy diet. The new dietary requirements of the American Heart Association (AHA) do not include a proposal to reduce eggs. The study by the European Food Information Committee (EUFIC) also favours the egg consumption. According to the study, eggs are the basis of quality nutrition and help regulate healthy body weight. According to 2010 dietary guideline in the USA, consuming one egg a day does not increase blood cholesterol levels and does not increase the risk of cardiovascular disease in healthy people. Therefore, it should be part of the weekly diet. Egg yolk contains cholesterol and saturated fat, so anyone can consume unlimited egg protein. The British Heart Foundation (BHF) describes that saturated 
fats have a much greater effect on cholesterol. Therefore, if allowed by a nutritionist, it can be part of the diet. According to the Australian guide, children and adults can eat 1-3 eggs a day. In case of pregnancy, the amount can be increased to 3-4. The wording of the Spanish Heart Foundation (SHF) is based on the fact that eggs are an essential food that provides energy in the body. According to this, it is not necessary to limit the consumption of eggs by healthy people. The WHO describes that egg yolk is rich in cholesterol but does not contain saturated fatty acids. If intake of the milk fat and meat is limited, there is no need to reduce consumption of egg yolk, only in a few cases [3].

Eggs are mostly consumed in fried and cooked form. Furthermore, it can also be used to enrich many foods. Enrichment is a special process where the biological value of food is increased by amino acids, fibers, vitamins, minerals, antioxidants, and other ingredients. The excellent utilization of eggs is mainly due to its complex protein content [4]. Animal based protein products contribute to the building of the muscular system and this also determines the energy balance of the body. The general protein need is 75-80 g (12-15 energy \%) in the human body. The best way to provide the organism with protein is a product of animal-based, as the complex protein is properly utilized as well. In our opinion and most recommendations, it is advised to consume 2-3 of the amount of eggs per week. The consumption of eggs should be reduced in case of high cholesterol. This is due to the high cholesterol content of eggs [5]. Eggs also have several other beneficial components, such as minerals, and vitamins [6].

As with all food, it is important to follow hygienic rules when storing and preparing egg-food. Due to this reason, the especial quality systems, rules, and documentations are required. The microorganisms that spread on eggs are especially dangerous during the summer months. One of the most significant of these is Salmonella, which is a Gram-negative bacterium [7]. The infection due to Salmonella results some severe symptoms, such as fever, abdominal pain, vomiting, diarrhea, intestinal inflammation, and loss of energy-balance in the human body [8, 9].

Eggs play an excellent role in international cuisine by maintaining hygiene and using the right kitchen technology. It is hoped that our manuscript can help to present the biological values of the eggs. In addition, we would like to make a consumption recommendation to increase egg popularity index at global level.

\section{Biological values and consumption-recommendations of eggs}

Eggs contain a complex animal protein and high in cholesterol (220-240 mg) so recommended to eat 2-3 pcs/week based on most suggestions and recommendations. Its vitamin content is excellent; primarily a source of vitamin D. Egg is rich in carotene and contains most of the minerals for example calcium, iron, and phosphorus. The quality of egg is significantly influenced by animal feed quality [10]. The protein, fat, and carbohydrate contents of eggs are summarized in Table 1.

Table 1. Energy, protein, fat and carbohydrate contents of whole egg, egg albumen, and egg yolk

\begin{tabular}{ccccc}
\hline Egg content per $50 \mathrm{~g}$ & Energy (kcal) & Protein (g) & Fat (g) & Carbohydrate (g) \\
\hline 1. Whole egg & 85 & 6.75 & 6 & 0.3 \\
2. Egg albumin & 29 & 6.4 & 0.15 & 0.35 \\
3. Egg yolk & 181 & 8.05 & 15.85 & 0.15 \\
\hline
\end{tabular}

Source: Rodler [11].

\section{The place of eggs in international gastronomy}

International gastronomy uses a wealth of products, ingredients, and spices for dish. The food has a rich world of taste and colour. Some nations prefer different products that others, so the cuisines of nations are very diverse. We recommend that everyone get to know these, which can enrich their own eating habits and kitchen technology as well. One of the most significant products is egg but pasta, meats, milk, and cheese, wine, wholemeal products, fruits and vegetables are also very popular. These ingredients are also used in many special diets that go well with international cuisine worldwide.

Consumption of eggs in fried and cooked form is recommended as well. A typical and well known dish can be a combination of ham and eggs with toast for breakfast. It can also be found in many creams, soups, pastas, and cakes [12]. This increases the biological value of the product.

It is also important to think about the hygiene rules when storing and preparing egg-foods. This is also supported by kitchen instructions, documentation, and quality rules (HACCP). Hygiene is imperative because eggs can be an excellent source of nutrients for some microorganisms, especially during the summer season. This microorganism for example is Salmonella, a Gram-negative bacteria. The well-known species of Salmonella are S. typhi, S. paratyphi, S. enteritidis, and S. enterica [13]. 


\section{Conclusions}

Eggs can provide valuable nutrients as part of a balanced diet. Eggs serve as a very good source of inexpensive high quality animal based protein. It contains useful biological components for the body and it has an excellent utilization as well. The content of vitamin D is the most significant; the content of iron, calcium, and phosphorus minerals is outstanding in the eggs. Due to high cholesterol levels, it is recommended to consume 2-3 pieces/week. Eggs are well used in international gastronomy in fried and cooked form. It is also suitable for enriched foods, which increases nutritional value of the product.

It is important to follow the rules of hygiene during the preparation of egg. This prevents the spread of microorganisms as Salmonella, which causes severe gastrointestinal symptoms, fever, and inflammation in the human body. As raw and undercooked eggs may contain Salmonella, hence, it is emphasized that egg must be properly boiled before consumption.

\section{Acknowledgement}

The authors are very thankful to Prof. Dr. R. K. Narayan for going through the manuscript.

\section{Author's Contribution}

All the authors contributed equally. They read the final version, and approved it for the publication.

\section{Conflict of Interest}

The authors declare that they do not have conflict of interest.

\section{Source of Financial Grant}

There was no financial support.

\section{References}

[1] García, V., Laca, A., Martínez, L. A., Paredes, B., Rendueles, M., and Díaz, M. (2015). Development and characterization of a new sweet egg based dessert formulation. International Journal of Gastronomy and Food Science, 2, 72-82.

[2] Valverde, D., Laca, A., Estrada, L. N., Paredes, B., Rendueles, M., and Díaz, M. (2016). Egg yolk fractions as basic ingredient in the development of new snack products. International Journal of Gastronomy and Food Science, 3, 23-29.

[3] Szőllősi, L., Molnár, Sz., Molnár, Gy., Horn, P., and Sütő, Z. (2017). Nutritional significance of eggs as a basic and functional food. The Hungarian Journal of Nutrition Marketing, 4, 7-22.

[4] Pérez-Bonilla, A., Jabbour, C., Frikha, M., Mirzail, S., Garcia, J., and Mateos, G. G. (2012). Effect of crude protein and fat content of diet on productive performance and egg quality traits of brown egg-laying hens with different initial body weight. Poultry Science, 91, 1400-1405.

[5] Chung, R. A., Rogler, J. C., and Stadelman, W. J. (1964). The effect of dietary cholesterol and different dietary fats on cholesterol content and lipid composition of egg yolk and various body tissues. Poultry Science, 221-228.

[6] Pal, M. (2019). Importance of hygienic processing of eggs for food safety. Food and Beverages Processing, 5, $22-24$.

[7] Hu, L., Cao, G., Brown, E. W., Allard, M. W., Ma, L. M., Khan, A. A., and Zhang, G. (2020). Antimicrobial resistance and related gene analysis of Salmonella from egg and chicken sources by whole-genome sequencing. Poultry Science, 99, 1-8.

[8] Pal, M. (2007). Zoonoses. Second Edition. Satyam Publishers, Jaipur, India.

[9] Bassetti, M., Nicco, E., Delfino, E., and Viscoli, C. (2010). Disseminated Salmonella paratyphi infection in a rheumatoid arthritis patient treated with infliximab. ClinicalMicrobiology and Infection, 16, 84-85.

[10] Sharma, M. K., Dinh, T., and Adhikari, P. A. (2020). Production performance, egg quality, and small intestine histomorphology of the laying hens supplemented with phytogenic feed additive. Journal of Applied Poultry Research, 29, 362-371.

[11] Rodler, I. (2005). Tápanyagtáblázat (Nutrienttable). Medicinakönyvkiadó Rt. Budapest/book/1-763.

[12] Oyeyinka, S. A., Olatunbosun, S., Oyeyinka, A. T., Balogun, M. A., Dauda, A. A., Obalowu, M. A., Badmos, A. A., and Joseph, J. K. (2019). Potentials of indigenous chicken eggs in the preparation of cake and chinchin. Journal of the Saudi Society of Agricultural Sciences, 18, 367-371.

[13] Zhou, Y., Kang, X., Meng, C., Xiong, D., Xu, Y., Geng, S., Pan, Z., and Jiao, X. (2020). Multiple PCR assay based on the cig Rgene for detection of Salmonella spp. and Salmonella Pullorum/Gallinarum identification. Poultry Science, 99, 5991-5998. 